УДК 37(091)(477)

DOI: $10.37026 / 2520-6427-2020-104-4-74-78$
Інна ПЕТРЕНКО,

здобувачка ступеня $P h D$

кафедри теорії і методики виховання

Рівненського державного гуманітарного університету

\title{
ДО ПИТАННЯ ПРО ОРГАНІЗАЦІЮ ПРОСТОРУ КЛАСНИХ КІМНАТ У ЦЕРКОВНОПАРАФІЯЛЬНИХ ШКОЛАХ УКРАЇНСЬКИХ ГУБЕРНІЙ (ДРУГА ПОЛОВИНА ХІХ - ПОЧАТОК ХХ СТ.)
}

У статті аналізується питання про організацію простору класних кімнат у иерковнопарафіяльних школах українських губерній у другій половині XIXна початку XX $\mathrm{cm}$.

На основі аналізу наукових праџь із проблеми, публікацій у тогочасній пресі, статистичних відомостей з'ясовано, щчо у другій половині ХІХ сm. під класні кімнати иерковнопарафіяльних шкіл найчастіше виділялися окремі кімнати у будинках священників, господарські примімення; під класні кімнати переобладнували споруди, які належали церкві; інколи школи розмішувалися в будинках сільських чиновників чи писаря, в управах, шинках. Організація простору таких класних кімнат була вкрай незадовільною, стан шкільних приміщень повсюдно оцінювався як украй слабкий.

Проаналізовані статистичні відомості стану шкільних приміщень, звіт обер-прокурора К. Побєдоносиева щуодо організації простору класних кімнат.

Наведено описи класних кімнат иерковнопарафіяльних шкіл, здійснені украӥнськими письменниками й культурно-освітніми діячами - Лесею Українкою, Б. Грінченком, І. Павлюком.

3'ясовано, щзо наприкінијі XIX - на початку ХX століття у контексті державної політики повної підтримки $i$ сприяння церковнопарафіяльним школам в украӥнських губерніях почався етап активного будівництва нових будівель шкіл, при організаиії простору класних кімнат иерковнопарафіяльних шкіл, за можливістю, враховувалися будівельні, архітектурні, санітарно-гігієнічні та педагогічні вимоги, як-от: новозбудовані иерковнопарафіяльні школи мали не лише окремий будинок, але й спеціальні шкільні господарські приміщення; класні кімнати мали відповідну площу, довжину, висоту, фіксоване розмімення вікон по одну сторону будівлі, місие для учительського столу, шафок тощзо.
Доведено, щзо досвід організаиії простору класних кімнат у структурі діяльності иерковнопарафіяльних шкіл на українських землях досліджуваного періоду є не тільки ціккавим, але й корисним для сучасності.

Ключові слова: класні кімнати, організація простору класних кімнат, иерковнопарафіяльні школи, украӥнські губернї.

In the article author analyzes the question of the organization of classroom space in church-parish schools of Ukrainian provinces in the second half of the XIXearly XX centuries.

Based on the analysis of scientific works on the problem, publications in the press of that time, statistical information, it was found that in the second half of the XIX century separate rooms for priests' houses and utility rooms were most often allocated for classrooms of church-parish schools; buildings belonging to the church were converted into classrooms; sometimes schools were located in the houses of village officials or clerks, in councils, taverns. The organization of the space of such classrooms was extremely unsatisfactory, the condition of school premises was generally assessed as extremely weak.

The statistical data of a condition of school premises, the report of the chief prosecutor K. Pobedonostsev concerning the organization of space of classrooms was analyzed.

Descriptions of classrooms of church-parish schools made by Ukrainian writers and cultural and educational figures - Lesya Ukrainka, B. Hrinchenko, I. Pavliuk are given.

It was found that at the end of the XIX - the beginning of the $X X$ century in the context of the state policy of full support and assistance to church-parish schools in the Ukrainian provinces the stage of active construction of new school buildings began, during organizing 
the space of classrooms of church-parish schools, construction, architectural, sanitary-hygienic, and pedagogical requirements were taken into account, if possible, such as newly built church-parish schools had not only a separate building but also a special school utility rooms; classrooms had the appropriate area, length, height, fixed placement of windows on one side of the building, space for a teacher's desk, lockers, etc.

It is proved that the experience of organizing the space of classrooms in the structure of church-parish schools in the Ukrainian lands of the studied period is not only interesting but also useful for today.

Key words: classrooms, organization of classroom space, Parochial school, Ukrainian governorates.

Постановка проблеми. Реформування сучасної шкільної освіти згідно з Концепцією Нової української школи передбачає набуття учнями низки компетентностей у відповідному сучасному освітньому середовищі, «яке забезпечить необхідні умови, засоби і технології для навчання учнів, освітян, батьків не лише в приміщенні навчального закладу» [10, с. 11].

У зв'язку з цим Концепція спонукає освітян актуалізувати наявні ідеї й обгрунтовувати нові підходи, що забезпечить ефективне функціонування Нової української школи. Зважаючи на це, набувають актуальності дослідження досвіду створення освітнього середовища в історико-педагогічному контексті. Це вивчення стосується не лише ставлення до дитини, оптимальних способів ефективного навчання, але й передбачає аналіз шкільних будівель, класних кімнат, меблів, санітарно-гігієнічних норм і правил організації шкільного навчання відповідних епох.

Особливо цікавим вважаємо досвід організації простору класних кімнат у церковнопарафіяльних школах, які у другій половині XIX - на початку XX ст. були дуже поширеними закладами в українських губерніях й вписали помітну сторінку в історію вітчизняної освіти та виховання. На нашу думку, практика організації простору класних кімнат у церковнопарафіяльних школах заслуговує ретельного вивчення в сучасних умовах.

Аналіз наукових досліджень і публікацій. Вивченням освітнього середовища закладу середньої освіти займалися В. Панов, В. Слободчиков [15]; предметно-просторове середовище закладу освіти досліджували Є. Бондаревська, Дж. Гібсон, В. Сєріков та ін.; сукупність системи впливів, можливостей, умов розвитку особистості в освітньому середовищі аналізували С. Дерябо, Н. Поліванова, В. Ясвін та ін. [21].

В історико-педагогічному контексті проблема організації простору класної кімнати практично не досліджена, хоча є окремі праці, присвячені організації шкіл. Приміром, Н. Палопеженцева (1894), П. Виноградова (1912) аналізували гігієнічні умови навчання дітей у сільських школах; С. Сірополко в праці «Історія освіти в Україні» (1937) на широкому фактологічному матеріалі статистичних збірників, звітів, архівних матеріалів про технічні характеристики шкільних приміщень здійснив загальну оцінку класних приміщень [18].

Сучасні науковці В. Звєрєв, К. Звєрєва, О. Гач (1989) вивчали матеріально-технічний стан сільських і недержавних закладів початкової освіти; С. Беленцов (2005), О. Клевцова і Н. Жиров (2016) досліджували технічний й санітарно-гігієнічний стан шкільних приміщень окремих регіонів царської Росії другої половини XIX - початку XX ст. [1;9].
Вивченням діяльності церковнопарафіяльних шкіл в окремих регіонах займалися Т. Джаман (1999) (розвиток народної освіти на Волині) [4]; В. Омельчук (2000) (освітні традиції духовних навчальних закладів Волині) [11]; І. Петренко (2004) (діяльність церковнопарафіяльних шкіл Лівобережжя) [16]; С. Бричок (2005) (організація навчально-виховного процесу в церковнопарафіяльних школах Волині) [2]; Г. Шелюк (2018) (досвід викладання окремих предметів у церковнопарафіяльних школах) [20].

Найбільш докладно фактологічна інформація стосовно організації шкільних приміщень церковнопарафіяльних шкіл представлена у праці В. Перерви «Церковні школи в Україні (кінець XVIII - поч. XX ст.): забутий світ» (2014) [15].

Однак аналіз організації простору класних кімнат церковнопарафіяльних шкіл на українських землях у другій половині XIX - на початку XX ст. до сьогодні окремо не здійснювався, що й зумовило вибір теми нашого дослідження.

Метою статті $\epsilon$ аналіз організації простору класних кімнат у церковнопарафіяльних школах у другій половині XIX - на початку XX ст. як важливої складової освітнього середовища.

Виклад основного матеріалу. У 60 -х роках XIX століття російський уряд провів ліберальну реформу народної освіти, яка була зумовлена ходом історичного розвитку країни: ріст економіки, розвиток нових суспільних відносин зумовили необхідність доступу до освіти дітей широких верств населення. У зв'язку з цим зросла мережа початкових шкіл, з'явилися нові типи навчальних закладів, удосконалювалася система підготовки вчителів, розширився зміст освіти, зростав рівень писемності населення, створювалися освітні товариства й організації [2, с. 31]. Найбільш розповсюдженим типом школи визначеного періоду були церковнопарафіяльні школи (або училища), школи грамоти, недільні школи, які знаходилися у підпорядкуванні Священного Синоду - соборного церковного уряду, який мав усі види вищої влади і через який діяла в церковному керівництві верховна самодержавна влада, оскільки Священний Синод підпорядковувався лише імператору Росії. Приміром, за даними одноденного перепису народних шкіл 18 січня 1911 р. 59,6\% з усіх шкіл в імперії були саме церковнопарафіяльними [18, с. 467].

Збільшення кількості шкіл безумовно вимагало нових шкільних приміщень. Однак у пореформеній країні коштів на будівництво шкіл не було, духовенству радили відкривати школи у власних будинках або в пристосованих приміщеннях. Сучасний історик В. Перерва наводить статистику по Київській митрополії, яка це підтверджує: «В 1861 р. в Таращанському повіті Київської губернії існувало вже 105 парафіяльних шкіл, 3 яких 91 містилася у власних будинках священників та причетників, 3 - у приміщеннях, подарованих священниками, 2 - у будинках мирян і ще 2 - у приміщеннях, наданих поміщиками. У Сквирському повіті цього року діяло 105 церковнопарафіяльних шкіл. Більшість із них (94) теж розташовувалися у власних житлах священників та причетників» [15, с. 186].

Найчастіше в будинках священників виділялися окремі кімнати, якщо ж будинок був надто малим, то класними кімнатами ставали господарські приміщення священника - сараї, клуні тощо. Досить часто під класні кімнати переобладнували споруди, які належали церкві - за ці приміщення не треба було платити, 
що інколи було визначальним. Таке явище було найбільш поширеним у Херсонській єпархії: приміром, у 1896-1897 н. р. 369 церковнопарафіяльних шкіл (більше половини) функціонували в церковних сторожках $[15$, с. 188$]$. Інколи школи розміщалися в будинках сільських чиновників чи писаря, в шинках та інших приміщеннях, де можна було просто поставити лавки для сидіння учнів і до обіду здійснювати їхнє навчання.

Наприкінці XIX ст. царський уряд, як стверджував С. Сірополко, «усіма засобами підтримував церковнопарафіяльні школи, асигнував значні кошти на їх утримання» $[18$, с. 354$]$. У цей період розвитком церковнопарафіяльних шкіл активно займався обер-прокурор Св. Синоду К. Побєдоносцев, який упродовж чверті століття очолював відомство. За його сприяння 13 червня 1884 р. були прийняті «Правила про церковнопарафіяльні школи», які створили для розвитку останніх більш сприятливі умови.

Саме із цього часу почався новий етап розвитку церковнопарафіяльних шкіл, позаяк за джерелами фінансових надходжень вони були більш державними, ніж початкові народні училища. Причиною того, що кількість церковнопарафіяльних шкіл збільшувалася 3 року в рік було, передусім, збільшення на них видатків із казни, адже задовільний фінансовий стан школи був запорукою забезпечення ії пристосованим до навчання приміщенням, необхідною літературою та кваліфікованим педагогічним персоналом. Як свідчать публікації досліджуваного періоду, спостерігачі церковнопарафіяльних шкіл Російської імперії сповідували думку, що «шкільне приміщення, вчитель і книга є трьома наріжними складовими церковно-шкільного життя» [8, с. 183].

Цілком логічно наприкінці XIX ст. в українських губерніях імперії почали активно будувати приміщення для церковнопарафіяльних шкіл. Саме поява власних нових приміщень давала можливість охопити навчанням більше учнів і відповідним чином організувати простір класної кімнати.

Особливо розвиненими церковнопарафіяльні школи були на Волині, де населення швидше віддавало дітей до церковної, аніж до польської школи. Приміром, лише за 1892/1893 навчальний рік на Волині було збудовано 63 церковнопарафіяльні школи, а у 1895 р. в губернії було побудовано 14 нових шкільних приміщень, більше половини діючих шкіл капітально відремонтовано [6, с. 301].

Якщо дозволяли кошти, школи будували дерев'яні, криті залізом. У школі була класна кімната, приміщення для вчителя і приміщення для гуртожитку на 15-20 учнів [2, с. 62]. Новозбудовані церковнопарафіяльні школи мали не лише окремий будинок, але й спеціальні шкільні господарські приміщення, квітник, колодязь, кілька розплідників, «отделение размножения», «пробный участок», «компостные кучи», «складочные места для торфа», «маточный сад», «места для прикопки на зиму корнеплодов», «рассадник огородных растений», виноградник, пасіку тощо [15, с. 197].

У звіті обер-прокурора К. Побєдоносцева за 1903-1904 роки йшлося про те, що до кінця 1904 р. 26513 початкових церковних шкіл мали свої вибудувані будинки, а 11189 шкіл містилися в найманих будинках [12].

Класні кімнати в новозбудованих церковнопарафіяльних школах відповідно до розроблених у ці роки рекомендацій, якщо дозволяли кошти, будували площею 120 м², позаяк вони служили єдиним багатофункціональним приміщенням, де навчалися діти різних вікових груп. Із часом (на початок XX ст.) площу класної кімнати зменшили до 60-72 м², з'явилися однакові вимоги до організації освітнього простору, що послужило підставою для розробки програм проєктування шкільних будинків. У кожній губернії розроблялися відповідні правила для будівлі шкільних приміщень, облаштування класних кімнат, в основу яких були покладені розробки професора Ф. Ерісмана [17].

Здійснений аналіз архівних джерел дає змогу узагальнити вимоги до класних кімнат церковнопарафіяльних шкіл: обов'язковим атрибутом у класній кімнаті були ікони, перед якими висіла лампадка, стіл учителя, велика чорна дошка, довгі парти $з$ лавками - на п'ять-десять дітей, невелика шафка для збереження шкільного приладдя - підручників, зошитів, олівців. У кращих школах на стінах прикріплювалися картини зі священної історії, починаючи від вигнання з раю Адами та Сви й закінчуючи зішестям Святого Духа на апостолів [2; 15-16].

Водночас стан шкільних приміщень, організація простору класних кімнат у ці роки оцінювалися вкрай неоднозначно. Поряд із відзначенням позитивних тенденцій досить розповсюдженою була критика й фіксування уваги на недоліках, притаманних церковнопарафіяльним школам. Так, у «Волинських Спархіальних відомостях» (1906) у рубриці «Из церковно-школьной хроники» знаходимо такі свідчення: «У школах недостатньо парт (замість парт використовувалися накладені на стовпчиках дошки), немає класних дошок, шаф; учительські квартири - без столів і стільців. Немає дров для опалювання шкіл. Несправні грубки. Учитель на печі диктує письмову роботу дітям. Учні пишуть. Інша картина: учитель меле на жорнах зерно на хліб, а учні виконують самостійну роботу. Часто в класі за грубкою учителі ставили ліжко» [7].

Певне уявлення про організацію простору класних кімнат у церковнопарафіяльних школах українських губерній досліджуваного періоду дають твори культурно-освітніх діячів України, зокрема Лесі Українки, Бориса Грінченка та ін.

Приміром, Леся Українка в одному з нарисів серії «Волинські образки» так описувала класну кімнату церковнопарафіяльної школи: «Шкільна кімната була немащена $з$ нерівною долівкою, така ж сама полупана, як і хата вчительки, посеред неї ряди шкільних лавок, в кутку чорна дошка з слідом крейди, в кінці хати стіл, за ним стілець, а над стільцем прибита на стіні лампа. За стіною хати - холодна (сільська тюрма). 3 класної кімнати тягнуло холодною вологістю, мов 3 льоху» [19].

Зі свого боку Б. Грінченко у статті «Школы Змиевского уезда Харьковской губернии», опублікованій у журналі «Русский народный учитель» у 1884 p., писав: «Мало не всі школи... містилися в одному будинкові $з$ волостю або сільською управою. Рідко в котрій з них припадало більш, як квадратовий аршин на учня, - вентиляції не було зовсім. У багатьох школах, що в них царював старшина або староста, відбувалися веселі, п'яні гулянки «начальства» 3 горілкою, піснями, танцями і так далі. Тут же складали одежу й різні речі заарештовані за невчасну плату податків, тут же зупинялися урядовці, що приїжджали на село в службових справах, тут чинили суд і розправу, тут 
повсякчас перебувало й вешталося багато зайвого народу. Взимку температура в цих школах доходила інколи до 13 градусів морозу, - чорнило замерзало, у дітей мало не одмерзали руки й ноги, - не могло бути й не було ніякої роботи. Печі здебільшого були несправні, та й палива майже не давали. Коли йшов дощ чи сніг, то по багатьох школах $з$ дірявими дахами ніде було сховатися від нього. Нічого й казати за книжки, мапи й найелементарніше, конче потрібне приладдя, - цього всього зовсім не було, - не було не те, що парт, а навіть звичайних лав, не було й класних таблиць» [3].

Подібний стан класних кімнат був і в інших українських губерніях. Підтвердження цього знаходимо в статті «Просвітна справа на селі» прогресивного публіциста того часу I. Павлюка, який, аналізуючи публікації в таких виданнях, як «Київська земська газета», «Киевские вести», «Одеський листок», «Рада», описав жалюгідне становище сільських шкіл в Україні, зокрема й класних кімнат: «...на Київщині в с. Лука будинок церковної школи старий, вогкий i холодний, паливом і освітленням школа не забезпечена... В с. Безпечнім в напівзруйнованому будинку, дуже подібнім до невеликої селянської комори, містяться: школа, сільська управа, «холодна» і зборня. Для школи призначено кімнату в 7 квадратних аршин, яка й під час найлютіших морозів стоїть 3 вибитими шибками у вікнах. Долівка земляна, вся в ямах. Тут то й учиться 80 школярів... В Кагарлицькій Слободі школа міститься в будинку, де раніше була корчма. Всюди вогкість, наука відбувається так-сяк, бо учителі стараються скоріше втекти від небезпечної вогкості. В с. Драбові на Полтавщині школа дуже давня, тісна, з невеликими вікнами... В деяких школах нема меблів, а іноді стільця й стола для учителя. Зошитів, дощок і приладів до писання, а то й підручників також нема і т. д.» [13, с.16].

Однак, як свідчать статистичні звіти, на початку XX століття завдяки збільшенню асигнувань держави на розвиток церковнопарафіяльних шкіл і постійній увазі громадськості матеріальне становище церковнопарафіяльних шкіл покращувалося: на одного учня в рік витрачалося 3 руб. 78 коп. сріблом, було збудовано низку нових шкіл. Приміром, у часописі «Волынские Епархиальные ведомости» зазначалося: «Новозбудовані школи мали хороший вигляд. Лише у 1901 році освячено декілька нових шкіл. 16 вересня 1901 р. було освячено нову школу в с. Плисці Кременецького повіту. Ця школа мала велику класну кімнату, бібліотеку, кухню, кладову і кімнату для вчителя. Довжина приміщення - 22 аршини, ширина - 12 аршин, в школі було 12 вікон, 10 дверей, 3 грубки. Будівництво обійшлося 1400 крб (одна тисяча - 3 казни, 400 - пожертвування). 8 жовтня 1901 року посвячена новозбудована школа у с. Блудові Острозького повіту. Школа цегляна, крита бляхою. Класна кімната квадратна, розміром 12 на 12 аршин, відповідала гігієнічним вимогам. Кошторисна вартість школи становила 1700 крб (750 - пожертвування селян, 950 - допомога Училищної ради) [5, с. 57]. Однак такі укомплектовані й добре обладнані школи й класні кімнати залишалися швидше винятками, аніж повсюдним явищем.

Проте, попри критику й незадовільний стан багатьох церковнопарафіяльних шкіл, очевидним $є$ те, що все ж наприкінці XIX - на початку XX ст. відбулася певна стабілізація вимог до шкільних будівель: за можливості будівельні, архітектурні, санітарно-гігіє- нічні та педагогічні вимоги до організації простору класних кімнат ураховувалися.

Висновки. Таким чином, презентована наукова розвідка дає змогу стверджувати, що в другій половині XIX ст. під класні кімнати церковнопарафіяльних шкіл найчастіше в будинках священників виділялися окремі кімнати, якщо ж будинок був надто малим, то класними кімнатами ставали господарські приміщення священника - сараї, клуні та ін. Досить часто під класні кімнати переобладнували споруди, що належали церкві. Інколи школи розміщувалися в будинках сільських чиновників чи писаря, в управах, шинках, де просто ставили лавки для сидіння учнів й до обіду здійснювали навчання. Тому організація простору таких класних кімнат була вкрай незадовільною, а стан шкільних приміщень повсюдно оцінювався як украй слабкий.

На початку XX століття на українських землях, попри труднощі й суттєві недоліки, при організації простору класних кімнат церковнопарафіяльних шкіл усе ж, по можливості, враховувалися будівельні, архітектурні, санітарно-гігієнічні та педагогічні вимоги, зокрема: новозбудовані церковнопарафіяльні школи мали не лише окремий будинок, а й спеціальні шкільні господарські приміщення; класні кімнати мали відповідну площу, довжину, висоту, фіксоване розміщення вікон по одну сторону будівлі, місце для учительського столу, шафок тощо.

Отже, в досвіді організації простору класних кімнат у структурі діяльності церковнопарафіяльних шкіл на українських землях досліджуваного періоду ми знаходимо важливі ідеї, які, безумовно, залишаються не тільки цікавими, але й корисними для сучасності. Найважливіша педагогічна ідея - це ідея адаптації наявного освітнього простору класної кімнати до можливостей і потреб краю, міста чи села, учнів, що $\epsilon$ найважливішим чинником, який забезпечить результативність функціонування початкової школи і збереження здоров'я учнів.

Перспективи подальших наукових розвідок вбачаємо у вивченні нових підходів до організації простору класної кімнати в структурі діяльності початкової школи України у 20-30-х рр. ХХ ст.

\section{СПИСОК ВИКОРИСТАНОЇ ЛІТЕРАТУРИ}

1. Беленцов С. И. Санитарно-гигиеническое состояние средних общеобразовательных учреждений во второй половине XIX - начале XX веков. Современные наукоемкие технологии. 2005. № 1. C. $128-131$.

2. Бричок С. Б. Церковнопарафіяльні школи в системі початкової освіти на Волині (друга половина XIX - 20-ті pp. XX століть) : дис. ... канд. пед. наук : 13.00.01 / Житомирський держ. ун-т ім. Івана Франка. Житомир, 2005. 184 с.

3. Гринченко Б. Школы Змиевского уезда Харьковской губернии. Русский народный учитель. 1884. № 2. C. 496.

4. Джаман Т. В. Розвиток народної освіти на Волині (XVIII-XIX ст.) : автореф. дис. ... канд. пед. наук : 13.00.01 / Терноп. держ. пед. ун-т ім. В. Гнатюка. Тернопіль, 1999. 20 с.

5. Епархиальные распоряжения и извести. Вольнские Епархиальные ведомости. 1902. № 5. С. 57.

6. Из церковно-школьной хроники. Вольнские Епархиальные ведомости. 1895. № 17. 
7. Из церковно-школьной хроники. Волынские Епархиальные ведомости. 1906. № 31. С. 1037.

8. К вопросу о нормальной деятельности уездных наблюдателей церковных школ. Черниговские епархиальные известия. Часть неофициальная. 1897. № 4. С. 160-165; № 5. С.183-188.

9. Клевцова О. В., Жиров Н. А. Школьные здания во второй половине XIX века: технические и гигиенические требования (на примере Орловской губернии). История: факты и символы. 2016. № 9. С. 8-14.

10. Нова українська школа: порадник для вчителя / за заг. ред. Н. М. Бібік. Київ : ТОВ «Видавничий дім «Плеяди». 2017. 206 с.

11. Омельчук В. В. Духовно-освітні традиції Волинського краю. Дубно, 2000. 108 с.

12. Отчет обер-прокурора. 1903-1904 год. СанктСетербург, 1909. С. 248.

13. Павлюк І. Просвітна справа на селі. Відень, 1917. $31 \mathrm{c}$.

14. Панов В. И. Психодидактика образовательных систем: теория и практика. Санкт-Петербург : Питер, 2007. 352 с.

15. Перерва В. Церковні школи в Україні (кінець XVIII - поч. XX ст.): забутий світ. Т. I. Загальна частина. Біла Церква : Видавець О. В. Пшонківський, 2014. 576 с.
16. Петренко I. М. Церковнопарафіяльні школи Лівобережної України в системі освітньої урядової політики царської Росії (1884-1917 рр.) : дис. ... канд. іст. наук : 07.00.01 / Національний педагогічний ун-т ім. М. П. Драгоманова. Київ, 2005. $245 \mathrm{c}$.

17. Примерные планы школьных зданий на 40-60 и 60-100 учеников. Московская губернская земская управа. Москва, 1898. 20 с.

18. Сірополко С. Історія освіти в Україні. Український Вільний університет; Друзі товариства імені Григорія Ващченка. Київ : Наукова думка, 2001. $912 \mathrm{c}$.

19. Українка Леся. Волинські образки. Твори : в 5 т. Київ, 1952. Т. 3. С. $570-575$.

20. Шелюк Г. В. Методичне забезпечення викладання математики: актуалізація досвіду церковнопарафіянських шкіл (кінець XIX - початок XX ст.). Інноватика у вихованні. Рівне : РДГУ, 2018. Вип. 8. C. $292-304$

21. Ясвин В. А. Образовательная среда: от моделирования к проектированию. Москва : Смысл, 2001. 365 c.

Дата надходження до редакиіï: 27.11.2020 p. 